\title{
Carpological features of certain Artemisia species distributed in Ukraine
}

\author{
Tetyana Vakulenko *, Tetyana Bagatska, (1) Olga Korablova **, (일an Gurnenko, \\ D Dzhamal Rakhmetov
}

M.M. Gryshko National Botanical Garden, National Academy of Sciences of Ukraine, Tymiryazyevska str. 1, 01014 Kyiv, Ukraine;

* botanicukr@gmail.com, ** okorablova@ukr.net

Received: 28.10 .2020 | Accepted: 21.12.2020 | Published: 30.12 .2020

\begin{abstract}
The achenes' micromorphological structure of six Artemisia species (A. absinthium, A. annua, A. argyi, A. dracunculus, A. marschalliana, and A. vulgaris) distributed in Ukraine was investigated with the aim to identify taxonomically significant carpological features for the studied species.

Fruits were collected from wild plants growing in the recreation areas of Kyiv and from the plants hosted in the living collection of the M.M. Gryshko National Botanical Garden of the NAS of Ukraine. Macromorphological features were studied with a binocular microscope Stemi 2000 Carl Zeiss. The ultrastructure of the surface was studied using a scanning electron microscope JSM-6700F JEOL, in the mode of secondary electron emission. Carbon spraying was performed using vacuum thermal evaporation of the vacuum universal post VUP-5M SELMI; platinum spraying was performed with an ion-plasma etching device JFC-1600 JEOL.

All investigated species have a well-expressed, true, multicellular, symmetrical, multi-row carpopodium but differ by its shape. The surface of $A$. annua achenes is reticulate-pitted due to the specific structure of the exocarp and the exotests located below it. Species with lobed and continuous apical rim and species without a rim around the place of attachment of the corolla were found. It was established that the primary ultrastructure of investigated fruits is caused by the shape and character of mucous cell arrangement; epidermal cells of the exocarp are mostly compressed, without clear boundaries. Mostly a thin and inconspicuous cuticle, sometimes wrinkled, with layers and small outgrowths, causes the secondary ultrastructure of these fruits. We believe that the mentioned carpological features may be used as additional criteria in combination with other features to identify studied species.
\end{abstract}

Keywords: Asteraceae, Artemisia, carpopodium, mucous complexes, primary ultrastructure, secondary ultrastructure, fruit

\section{Introduction}

The genus Artemisia L. is the largest in the tribe Anthemideae Cass. of the family Asteraceae Dumort, reaching up to 550 species spread throughout the Northern Hemisphere (Mungalov, 2004; Beer, 2005; Boyko, 2011). There are 30 Artemisia species distributed in Ukraine (Boyko, 2013). The systematics of this genus is complicated due to significant intraspecific variability of morphological features. Such a situation encourages searching for new diagnostic criteria. Carpological features may be among the solutions because their importance for the taxonomy and phylogeny of Artemisia has been proved (Boyko, 2011; Boyko \& Novozhilova, 2018; Bagatskaya \& Vakulenko, 2013).

Artemisia fruit is an indehiscent achene that develops from the inferior bicarpellate (dimerous) ovary. The mature seed cover is formed by three structural elements: the pericarp, the spermoderm, and the endosperm's remnants. The pericarp in 
Artemisia is quite simplified, formed by a single layer of epidermal cells, remnants of vascular bundles, and an additional layer of subepidermal cells (Boyko, 2011).

The exocarp of Artemisia fruit contains mucous cells. Mucous cells are located solitary or in the so-called 'mucous complexes' forming longitudinal raised sleeper-like or laddershaped ribs with tangentially elongated cells (Yakovleva et al., 2002). The cells of mucous complexes differ significantly from the regular epidermal cells. Such complexes can be of different length, sometimes even as long as achene (Boyko, 2011).

Scanning electron microscopy (SEM) is extremely important for the fruit micromorphology. It allows to study the ultrastructure of integuments in more details and to elucidate additional carpological features such as the structure of the carpopodium (the area of separation of the achene from the perianth placed around the fruit scar), the structure of the apical bowl (the area of attachment of the corolla, surrounded by a roller or rim), and primary and secondary ultrastructure of the surface (Mukherjee \& Nordenstam, 2010; Boyko, 2011). SEM of the fruits often helps to resolve taxonomic issues. Hence, the work aimed to study the micromorphology of achenes of six Artemisia species represented in the flora of Ukraine and determine carpological features that could be applied to distinguish these taxa.

\section{Material and methods}

Mature achenes of Artemisia absinthium L., A. annua L., A. argyi Lévl. et Vaniot, A. dracunculus L., A. marschalliana Spreng, and A. vulgaris L. were studied. Achenes were collected from the wild plants growing in the recreation areas of Kyiv (two localities - $50.511839 \mathrm{~N}, 30.399793 \mathrm{E}$ and $50.514308 \mathrm{~N}$, $30.387294 \mathrm{E})$, as well as from the collection of aromatic plants at the M.M. Gryshko National Botanical Garden of the NAS of Ukraine $(50.416432 \mathrm{~N}, 30.557891 \mathrm{E})$. All the investigated localities are in the same Forest-Steppe zone of Ukraine.

Macromorphological features were analyzed under light microscopy (LM) using a binocular microscope Stemi 2000, Carl Zeiss (Germany). Digital processing of images was carried out in the program Axio Vision. The ultrastructure of the surface was studied using a scanning electron microscope JSM-6700F, JEOL (Japan) in the mode of secondary electron emission. Carbon spraying was performed by the method of vacuum thermal evaporation of the vacuum universal post VUP-5M, SELMI (Ukraine). Platinum spraying was performed using an ion-plasma etching device, JFC-1600, JEOL (Japan).

General fruit descriptions are provided following Artyushenko \& Fedorov (1986) and Bojnanský \& Fargašová (2007). To characterize the ultrastructure, we used Barthlott (1981) terminology, according to which the difference between primary and secondary structure can be observed. Applied terminology has also been crosschecked accordingly to Stern (1992). Consequently, it was accepted that macromorphological features (shape of epidermal cells, curvature, height, thickness and relief of their periclinal and anticlinal walls, the origin of indumentum, etc.) determine the primary structure of the fruits in studied species. By contrast, the secondary structure is determined by the micromorphology and characterizes the cuticle sculpture.

\section{Results}

\section{Artemisia absinthium}

Achenes are oblong-wedge-shaped, slightly curved dorsally, 0.93-1.07 × 0.37-0.45 mm, planar compressed-polygonal. Ribs smoothed, weakly defined. The surface is bare, glossy; the relief is longitudinally striped, the color is brown or light brown (Fig. 1 I). The tip is widened, slightly beveled, the place of attachment of the corolla with a diameter of 220-250 $\mu \mathrm{m}$, surrounded by a low blade rim (Fig. 2 I - B). The base is narrow, carpopodium basal, whitish, triangular-rounded, $80 \times$ $110 \mu \mathrm{m}$, not wrapped, with four-five rows of cells. Carpopodial cells $15-25 \times 5-12 \mu \mathrm{m}$, tangentially elongated, rectangular in the lower rows, often polygonal in the upper rows, due to which the dividing line between the carpopodium and the achene body is wavy (Fig. 2 I - A). The primary ultrastructure of the carpopodium is well defined, the cell boundaries are clearly visible, and anticline walls are thin, straight, or slightly rounded. The outer periclinal walls are convex. 


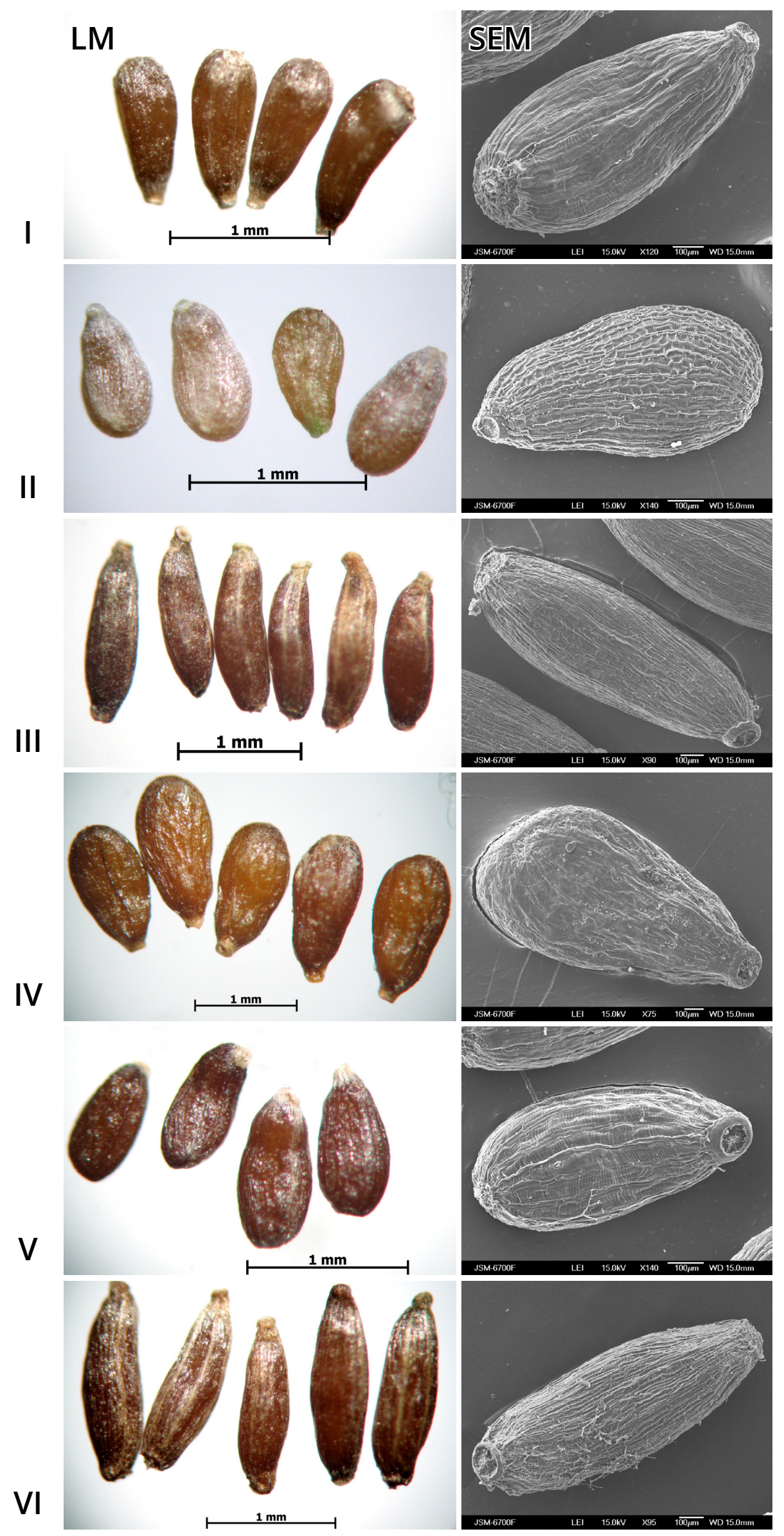

Figure 1. General view of Artemisia fruits under the light (LM) and scanning electron (SEM) microscopes: I - A. absinthium; II - A. annua; III - A. argyi; IV- A. dracunculus; V - A. marschalliana; VI - A. vulgaris. 


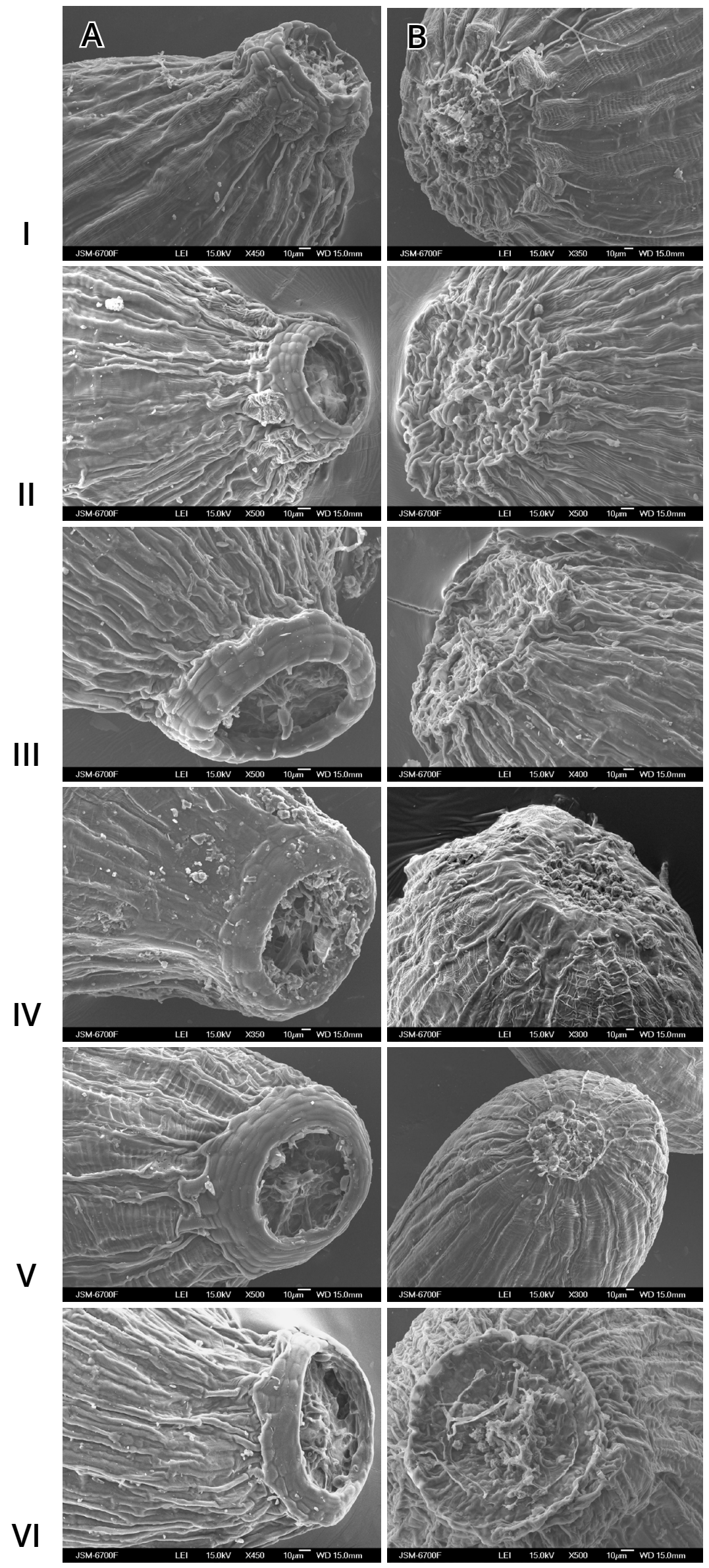

Figure 2. SEM structure of carpopodium (A) and apical bowl (B) of Artemisia species: I - A. absinthium; II - A. annua; III - A. argyi; IV-A. dracunculus; V - A. marschalliana; VI - A. vulgaris. 

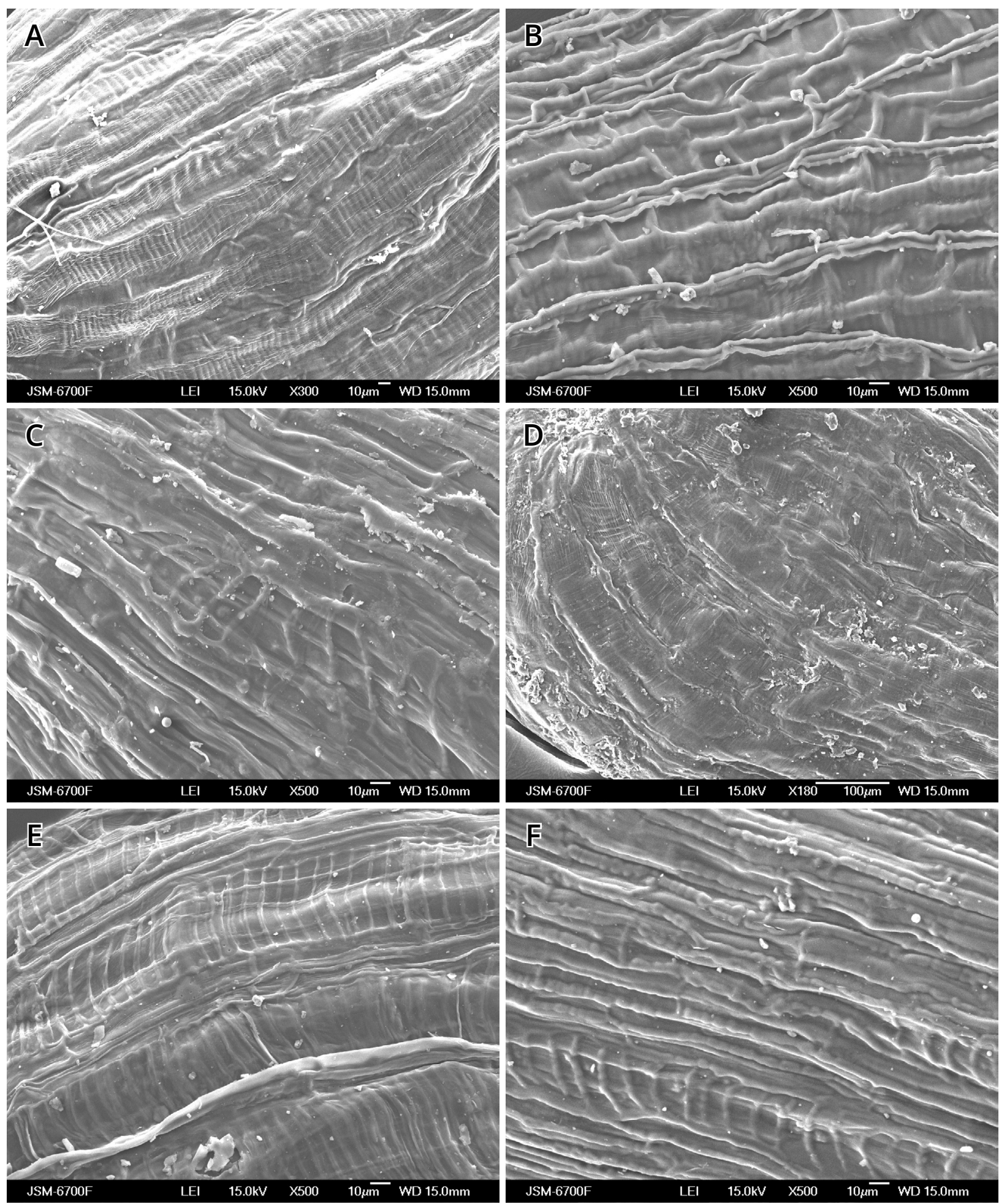

Figure 3. Fragments of the surface of achenes of species of the genus Artemisia with complexes of mucous cells under the SEM: I - A. absinthium; II - A. annua; III - A. argyi; IV- A. dracunculus; V - A. marschalliana; $\mathrm{VI}-\mathrm{A}$. vulgaris.

A smooth cuticle represents the secondary ultrastructure.

Mucous complexes in the form of longitudinal single-row strands consist of mucous cells. Most of the cords rise above the achene's surface, extending from the apex to the base, but there are also short complexes containing 15-30 mucous cells (Fig. 3). The primary ultrastructure of the strands is well-visible - they consist of rectangular tangentially elongated cells up to $15-25 \mu \mathrm{m}$ long, tightly spaced one below the other (Fig. 4 A). Anticline walls of mucous cells are straight, thickened, with raised edges. 


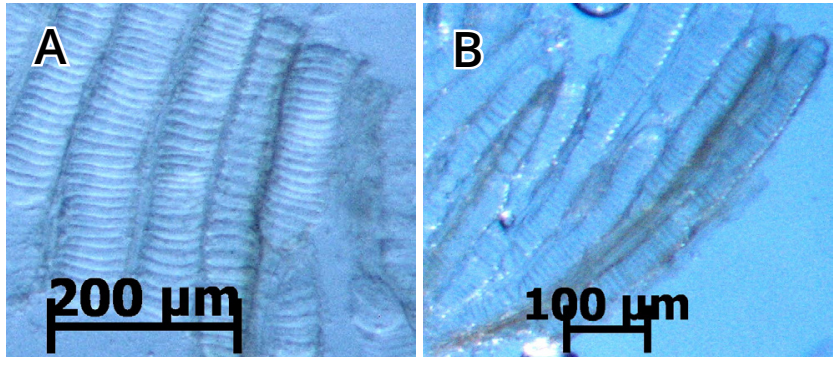

Figure 4. The strands of the mucous cells of Artemisia absinthium (A) and A. marschalliana (B) under the LM.

Outer periclinal walls - concave or almost flat, densely covered with longitudinal folds. The exocarp's epidermal cells, which do not contain mucus, situate between the strands of mucous complexes in two-three rows. According to the primary ultrastructure, they are longitudinally elongated, prosenchymatic, with almost straight or tortuous thickened raised anticline walls and concave outer periclinal, often folded or grooved. In some places, the primary ultrastructure is not welldefined, and the cell boundaries are weakly visible. The secondary ultrastructure is weakly expressed - the cuticle is mostly smooth, occasionally slightly wavy, with isolated bumpy cuticular outgrowths.

\section{Artemisia annua}

Achenes are pear-shaped, 0.75-0.85 × 0.39$0.45 \mathrm{~mm}$, slightly curved. The surface is bare, glossy; the relief is fine-mesh, with narrow longitudinal ribs, straw-brown color, strawyellowish (Fig. 1 II). The top is widened and rounded. The place of attachment of the corolla is slightly bent on the ventral side, rounded, 100-120 $\mu \mathrm{m}$ in diameter, often with remnants of stylopodium in the center in the form of a whitish column, surrounded by a low solid rim (Fig. 2 B - II). The base is narrow, straight, or slightly beveled. Carpopodium is basal, round, annular, symmetrical, up to 50$75 \mu \mathrm{m}$ in diameter, not wrapped. Carpopodial cells are tangentially elongated, 10-15 × 4-8 $\mu \mathrm{m}$, upper row cells are occasionally polygonal. The demarcation line between the carpopodium and the achene body is slightly wavy (Fig. $2 \mathrm{~A}-\mathrm{II}$ ). The primary ultrastructure is well-defined; the anticline walls of carpopodial cells are thin and straight; external periclinal walls - convex and thickened. A smooth cuticle represents the secondary ultrastructure.
Mucous cells are grouped in complexes that extend in single-row strands along the achene, barely rising above its body. The strands of mucous complexes can be short, sometimes bifurcated, or, conversely, combined into one. These strands have wavy contours formed by tangentially elongated mucous cells of different lengths (from 20 to $40 \mu \mathrm{m})$. The primary ultrastructure of the strands is relatively well-defined. Anticlinal walls are significantly raised, mostly wavy and indistinct. External periclinal walls are concave or almost flat, permeated with branched more or less rounded folds, forming a reticulate-pitted relief (Fig. 3). Exocarp cells are rectangular or prismatic, compressed by mucous strands. The primary ultrastructure is poorly visible, anticline walls with significantly raised wavy edges. External periclinal walls are often concave, sink into the cells' cavities; their folds are weakly noticeable. The secondary ultrastructure is defined differently in various parts of the achene. It is longitudinally wrinkled near the place of attachment of the corolla and around the carpopodium. In some places, there are cuticular bumps, in other places often without noticeable differentiation.

\section{Artemisia argyi}

Achenes are fusiform, with a straight truncated-narrowed apex 1.34-1.45 × 0.39$0.50 \mathrm{~mm}$, rounded-depressed in crosssection. The surface is longitudinally wrinkled, bare, and glossy, with several light ribs, dark brown (Fig. 1 III). The place of attachment of the corolla is rounded or compressed-rounded, with a diameter of up to $210-250 \mu \mathrm{m}$, in the center with the remnants of stylopodium, surrounded by a low solid rim (Fig. 2 B - III). The base is narrow, sometimes obliquely cut or turned to the side. Carpopodium basal, light yellowish, up to $120-150 \mu \mathrm{m}$ in diameter, slightly wider than the base, symmetrical, round, wrapped; consists of five-seven rows of cells. The line of demarcation between the carpopodium and the achene body is clear, almost smooth; the transition zone between the carpopodium and the rest of the achene is often twisted (Fig. $2 \mathrm{~A}$ - III). The primary ultrastructure is well-defined, carpopodial cells are tangentially elongated, $15-25 \times 8-10 \mu \mathrm{m}$, with clear boundaries. Anticlinal walls are 
thin, straight, or slightly curved. The outer periclinal walls are convex, thickened. The secondary ultrastructure is not pronounced; the cuticular relief is smooth.

Mucous complexes form short, sometimes two-row longitudinal strands, none of which extends from the base to the top. Mucous cells are tangentially elongated to $10-15 \mu \mathrm{m}$ and are barely raised over the strands' surface (Fig. 3). Their primary ultrastructure is well visible only in a few places. The anticline walls are thickened, straight. The outer periclinal walls are flat or concave, often with a rounded tubercle in the center. The exocarp's epidermal cells are 4-5-angular, longitudinally elongated, significantly compressed, and often smooth. Their borders are the best manifested on the ventral side; anticlinal walls are thickened, with raised edges, periclinal - concave, rarely flat, sometimes chaotically folded. Ribs formed by the vascular bundles complicate the primary ultrastructure. Schizogenic secretory containers are present. The secondary ultrastructure is poorly visible, only in a few places. The cuticular layer is slightly wavy, with occasionally noticeable cuticular bumps.

\section{Artemisia dracunculus}

Achenes are pear-shaped, 1.37-1.52 × 0.65$0.77 \mathrm{~mm}$, elliptical in cross-section. The top is bluntly rounded, sometimes slightly beveled (Fig. $1 \mathrm{IV}$ ). The fastening of a corolla is not outlined, inclined towards the ventral party (Fig. 2 B - IV). The ribs are indistinct. In some places, they are entirely smooth, brownish, and reddish-brown; the ventral rib is the most well-defined. The surface is shiny, bare; the relief is longitudinally wrinkled; the color is dark brown. Carpopodium basal, straight or slightly curved on the ventral side, $150 \times$ $200 \mu \mathrm{m}$, oval, symmetrical, wrapped, with five-six rows of cells. Cells are tangentially elongated, $20-25 \times 10-15 \mu \mathrm{m}$, quadrangular, occasionally polygonal in the upper row. The demarcation line is clear, almost equal along all its length (Fig. $2 \mathrm{~A}-\mathrm{IV}$ ). The primary structure is less pronounced than in previous species. The boundaries of carpopodial cells are seen only partly in the upper rows, while the lower rows remain smoothed cell contours. Anticlinal walls are thin, straight, or slightly curved, the outer periclinal - thickened, convex. The secondary ultrastructure of the cuticle is straightened, smooth.

Mucous complexes represent smooth, different length longitudinal strands that are flush with the achene body and undefined in some places (Fig. 3). Mucous cells are tangentially elongated; anticline walls are slightly thickened, straight. The outer periclinal walls are concave or almost flat, sometimes chaotically folded, especially around the apex. Chaotic cuticular layers represent the secondary ultrastructure. The primary structure of the epidermal cells of the exocarp is also weakly defined. Only in some places, solitary prosenchymatic cells with thickened curved anticlinal walls and concave periclinal are visible. The ribs are more or less visible in the upper part and at the base of the achenes; occasionally, above them, there are located schizogenic secretory containers. The secondary ultrastructure is indistinct; the wrinkled surface of the cuticle appears only in some places.

\section{Artemisia marschalliana}

Achenes are inverted ovate, rounded in crosssection, $0.80-1.05 \times 0.37-0.47 \mathrm{~mm}$, sometimes slightly curved in the dorsal-ventral projection, with more convex backside, and the ventral part that is concave. The surface is bare, slightly shiny, the ribs are smooth, and the relief is longitudinally striped, with dark brown color (Fig. $1 \mathrm{~V}$ ). The apex is wide, bluntly rounded, often obliquely cut. The corolla's attachment place is rounded, with a diameter of 80-90 $\mu \mathrm{m}$, surrounded by a low light rim (Fig. $2 \mathrm{~B}-\mathrm{V}$ ). The base is narrow. Basal carpopodium, slightly bent to the side, whitish, annular, symmetrical, and wrapped, consists of six-seven rows of cells. Carpopodial cells are tangentially elongated, rectangular, of different lengths, 13-25 $\times$ 7-12 $\mu \mathrm{m}$. The upper row often consists of polygonal cells, due to which the line of demarcation between the carpopodium and the achene body is wavy (Fig. $2 \mathrm{~A}-\mathrm{V}$ ). At the primary ultrastructure level, the anticline walls of carpopodial cells are straight or curved and thin, while the outer periclinal walls are thickened and convex. The cuticle is without noticeable differentiation.

Mucous complexes are in the form of longitudinal, slightly raised strands extending 
from the base to the top. Mucous cells are rectangular, 10-25 $\mu \mathrm{m}$ long, placed by twothree side by side, so the strands are wider than in other species (Fig. 3). Their anticlinal walls are straight, slightly thickened; the outer periclinal - concave in the cell cavity or smooth, sometimes in the middle with a tubercle (Fig. 4 B). The secondary ultrastructure of mucous cells is often characterized by a straightened cuticle, which is slightly transversely or longitudinallywrinkled around the apex and the base.

The exocarp's epidermal cell boundaries are poorly visible, preferably from the achene's ventral side, where they are elongated along the central axis. Anticline walls are more or less straight, with raised fine-toothed edges. The outer periclinal wall of epidermal cells is concave, with many chaotic folds, which often overlap, hiding the primary ultrastructure. The ribs are smooth; occasionally, schizogenic secretory containers are located on them. The secondary microstructure is not clearly defined; flat or wrinkled plates represent cuticular layers.

\section{Artemisia vulgaris}

Achenes are fusiform, 1.50-1.60 × 0.40$0.47 \mathrm{~mm}$, oval in section, with a narrowed tip and base. The surface is glossy, bare, longitudinally wrinkled, brown or dark brown, with light yellowish ribs (Fig. $1 \mathrm{VI}$ ). The place of attachment of the corolla is well visible, situated slightly to the side, round, surrounded by a high thin solid translucent rim up to $150 \mu \mathrm{m}$ in diameter (Fig. $2 \mathrm{~B}-\mathrm{VI}$ ). Basal carpopodium, placed directly or slightly moved to the side, oval, symmetrical, wrapped, 90-100 × 140-150 $\mu \mathrm{m}$, and consists of seveneight rows of cells. Carpopodial cells are tangentially elongated, $10-12 \times 4-8 \mu \mathrm{m}$; the upper row is often made of polygonal cells; the demarcation line is clearly visible, wavy (Fig. 2 A - VI). The primary ultrastructure of the carpopodium in the lower rows is smooth, without clear boundaries. It is better defined in the upper rows - the anticlinal walls are straight, thin, the outer periclinal are thickened, slightly convex, sometimes flat. The secondary ultrastructure is not defined; the cuticle is straightened.

Mucous cells are joined in small separate groups or complexes in the form of short cords, located almost on the same level as the achenes' body (Fig. 3). Mucous cells in the strands are sometimes placed by two in a row. Their primary ultrastructure is indistinct. Thickened straight anticlinal walls have raised edges. Concave outer periclinal walls are sometimes chaotically folded. The exocarp epidermis cells are located between the mucous complexes in three-four or more rows, with thickened, mostly straight anticlinal walls. The outer periclinal walls are concave or flat, sometimes convex, sometimes folded. Above the vascular bundles, there are sometimes schizogenic secretory containers. The secondary ultrastructure of exocarp cells is weakly defined; only in certain places, mainly at the ends, the transversely wrinkled cuticle is seen, with occasional cuticular tubercles.

\section{Discussion}

Our studies showed that the achenes of the described species have structural elements that are typical to other Asteraceae members (Boyko, 2011). Three types of achenes were initially distinguished for the genus Artemisia: narrow-lanceolate, narrowly elliptical, and inverted ovate (Korobkov, 1973), however later, the list was expanded (Ouyahaya, 1995; Beer, 2005; Boyko, 2011). Inverted ovate (A. marschalliana), pear-shaped (A. dracunculus and A. annua), spindle-shaped (A. argyi and A. vulgaris), and narrow-wedgeshaped (A. absinthium) achenes were found.

All studied species have a well-developed carpopodium consisting of thick-walled cells, which differ from the regular cells of the achene. Carpopodium is true, multicellular, annular, symmetrical, multiline, with foureight rows of tangentially elongated cells with thickened convex outer periclinal walls and more or less straight anticlinal ones. Previously, we described a false carpopodium with concave outer periclinal walls for A. argyi and A. vulgaris (Bagatskaya \& Vakulenko, 2013). More advanced SEM technique has revealed in these species a true carpopodium with convex outer periclinal walls. This discrepancy may be related to the achenes' location in the calathium, the degree of their maturity and quality, as well as insufficient resolution of the light microscope (Boyko, 2011). Carpopodium in the studied species is round (A. annua, A. argyi, 
and A. marschalliana), oval (A. dracunculus and A. vulgaris), or triangular-round (A absinthium). In A. annua, A. absinthium, and A. vulgaris, carpopodial cells are located only on the outer surface of the achene, and carpopodium is not wrapped. In A. argyi, A. dracunculus, and A. marschalliana, one-two lower rows of carpopodial cells enter the inner surface of the basal part of the achene, forming a wrapped carpopodium. In A. absinthium, A. annua, A. argyi, and A. marschalliana, the primary ultrastructure of the carpopodium is well defined, and cells have clear boundaries. In A. dracunculus and A. vulgaris, the primary ultrastructure is fuzzy; the cells' contours are visible only in the upper rows; they are smooth in the rows below. Straightened smooth cuticle characterizes the secondary ultrastructure of the carpopodium.

The place of attachment of the corolla at the apex of the achene (apical bowl) is well defined in all species. It is outlined by a rim, which is placed in the middle of the apex or is slightly shifted to the side due to the topography of the fruit (Boyko, 2011). The presence and nature of the rim are strictly related to the embryo size. The rim appears due to the embryo's folding due to drying of the achene (Korobkov, 1973). In A. absinthium, the rim is lobed, rounded, formed by the anticlinal walls of mucous cells. In other investigated species, the rim is solid, rounded, symmetrical, formed by the anticlinal walls of both mucous and epidermal cells of the exocarp. In A. vulgaris the rim is the highest and has the shape of a thin membranous crown. In A. dracunculus the place of attachment of a corolla is well defined, but the rim is absent. The rim with smallest diameter is typical to A. marschalliana (up to $90 \mu \mathrm{m}$ ) and A. annua (up to $100 \mu \mathrm{m}$ ); in other species, it is almost twice as wide (220$250 \mu \mathrm{m})$.

Specialized mucous cells were found in the exocarp of the studied species. Among Asteraceae, such mucous cell complexes were found only in the achenes of the representatives of the tribe Anthemideae. These complexes serve as a reliable taxonomic sign of this tribe but do not distinguish genera (Yakovleva et al., 2002; Mungalov, 2004; Boyko, 2010). Mucous cells are usually grouped into mucous complexes in the form of longitudinal spherical cords extending from the apex to the base of the achene. These cords are raised above the achene's surface in A. absinthium, A. argyi, and A. marschalliana. However, in A. annua, A. dracunculus, and A. vulgaris, they are located almost on the exocarp surface level. In the achenes of A. vulgaris that we studied, the cords were poorly visible; the mucous cells were located mainly in separate groups. Although some literature data indicate long mucous cords in A. vulgaris, other sources reported their absence (Korobkov, 1973; Boyko, 2013). This discrepancy could be explained by the phenomenon when in some Artemisia species, the mucous cells lose their functions but retain their characteristic structure.

The ribbed surface of the achenes of Artemisia can have a different origin. The SEM made it possible to clarify the nature of the microrelief of studied species' achenes. Many authors (Korobkov, 1973; Beer, 2005; Boyko, 2011) distinguish between longitudinal streaking of achenes (due to the presence in the epidermis of the exocarp of large mucous complexes represented by strands longitudinally raised above the body of the achene) and longitudinal wrinkles, which are loosely adjacent to the achene. Among the studied achenes, the longitudinally striped surface we found in A. absinthium and A. marschalliana. At the same time, achenes of A. argyi, A. dracunculus, and A. vulgaris are characterized by a longitudinally wrinkled surface. In A. annua achenes, the nature of the surface is somewhat different from other species: the mucous membranes are quite broad; the main cells of the exocarp are arranged between them in a row and significantly compressed. The mucous cells' outer periclinal walls are concave or flat, and wide rounded branched folds clearly appear through them, forming a kind of reticular pattern. This appearance of the achene's surface with thin embryo is not caused by the structure of the exocarp solely. Also, it is affected by the relief of the exotests placed under it, like in many asters with a tight fit of the embryo to the test (Boyko \& Novozhilova, 2018). We defined the type of surface found in A. annua as reticulate-pitted.

On the surface of the achenes of A. argyi, A. dracunculus, and A. vulgaris schizogenic secretory containers with well-marked polygonally rounded squamous cells were found. The primary ultrastructure of mucous cells and regular exocarp cells located 
between the mucous cords is somewhat different. Mucous cells are the most welldefined. In all investigated species, they have relatively clear boundaries; their anticlinal walls are straight (A. absinthium, A. argyi, and A. dracunculus), or slightly wavy, unevenly thickened (A. annua and A. vulgaris). The outer periclinal walls are usually concave or flat, sometimes with a tubercle in the middle (A. argyi and A. marschalliana) that protrudes through the outer wall. Such bumps may indicate the presence in exocarp cells of various crystalline inclusions or individual large crystals of calcium oxalate, which is characteristic of many wormwoods (Boyko, 2014). The primary ultrastructure of epidermal cells of the exocarp is weakly defined. These cells are significantly compressed, often without clear boundaries, with unevenly thickened anticlinal walls, the edges of which are straight (A. argyi and A. dracunculus), wavy (A. absinthium and A. marschalliana), or fine-toothed (A. annua). The outer periclinal wall is concave, rarely flat, or slightly convex; its surface is often wrinkled or folded. It is proved that such folding is formed not by the cuticle but by the irregularities of the outermost periclinal walls (Yakovleva et al., 2002). Secondary ultrastructure is defined differently in different Artemisia species. In particular, A. absinthium is characterized by a pronounced folded cuticle over the mucous membranes. It was found that the thickened cuticle characterizes the secondary structure of A. marschaliana. Sometimes such thickened layers form cuticular conglomerates. In other species (A. absinthium, A. annua, and A. vulgaris), the cuticle is more or less straight; cuticular tubercles and growths are only occasionally present on its surface.

\section{Conclusions}

As a result of comparative morphological analysis of achenes of six species of the genus Artemisia, a specific variety of individual structural elements was revealed, the features of which can be used comprehensively for reliable identification of species. These features can be used to identify investigated Artemisia species by fruit, especially when their recognition based on macromorphological features is complicated.
The set of diagnostic carpological criteria to distinguish Artemisia species should include: a) such peculiarities of the carpopodium as nature of the line of demarcation between the carpopodium and the achene body, and location of carpopodial cells on the inner surface of the basal part of the achene; b) presence or absence of apical rim; c) features of primary and secondary ultrastructure of the exocarp's strands and epidermal cells.

\section{References}

Artyushenko, Z. T., \& Fedorov, A. A. (1986). Atlas of descriptive morphology of higher plants. Embryo. Leningrad: Nauka. (In Russian)

Bagatskaya, T. S., \& Vakulenko, T. B. (2013). Morphological features of achenes Artemisia argyi Leveillie et Vaniot and Artemisia vulgaris L. (Asteraceae). Bulletin of Udmurdskiy University, 3, 162-165. (In Russian)

Barthlott, W. (1981). Epidermal and seed surface characters of plants: Systematic applicability and some evolutionary aspects. Nordic Journal of Botany 1(3), 345-355. https://doi. org/10.1111/j.1756-1051.1981.tb00704.x

Beer, A. S. (2005). Comparative biomorphological study of the Eastern European representatives of the genus Artemisia L. (Asteraceae Dumort.). [PhD thesis abstract]. Moscow. (In Russian)

Bojnanský, V., \& Fargašová, A. (2007). Atlas of seeds and fruits of Central and East-European flora. Dordrecht: Springer.

Boyko, E. V. (2010). Morphological and anatomical structure of achenes of Far Eastern species of the genera Kalimeris and Boltonia (Asteraceae: Astereae). Turczaninowia, 13(4), 58-64. (In Russian)

Boyko, E. V. (2011). Taxonomy and resources of Far Eastern species of the family Asteraceae. [PhD thesis abstract]. Vladivostok. (In Russian)

Boyko, E. V. (2013). Micromorphology of achenes of species of the genus Artemisia (Anthemideae - Asteraceae). Turczaninowia, 16(2), 91-105. (In Russian)

Boyko, E. V. (2014). Crystals in the tissues of achenes of Asteraceae species. Turczaninowia, 17(3), 58-64. (In Russian)

Boyko, E. V., \& Novozhilova, E. V. (2018). Structure of the seed coat of Asteraceae species. I. Tribes Arctotideae, Cardueae, Mutisieae, Vernonieae. Turczaninowia, 21(4), 44-62. (In Russian). https:// doi.org/10.14258/turczaninowia.21.4.6 
Boyko, G. V. (2013). Distribution of species of the genus Artemisia L. in the flora of Ukraine. Industrial Botany, 13, 73-79. (In Russian)

Korobkov, A. A. (1973). Morphological and anatomical features of sagebrush achenes (Artemisia ssp.) in the North-East of the USSR. Botanicheskii Zhurnal, 58(9), 1302-1315. (In Russian)

Mukherjee, S. K., \& Nordenstam, B. (2010). Distribution of calcium oxalate crystals in the cypselar walls in some members of the Compositae and their taxonomic significance. Compositae Newsletter, 48, 63-88.
Mungalov, E. A. (2004). Wormwood of the Altai Mountains. $[\mathrm{PhD}$ thesis abstract]. Tomsk. (In Russian)

Ouyahya, A. (1995). Étude anatomique preliminare des akènes de quelques Artemisia dans le bassin méditerranéen occidental. Compositae Newsletter, 26, 40-48.

Stern, W. T. (1992). Botanical Latin. Oxford.

Yakovleva, O. V., Korobkov, A. A., \& Boyko, E. V. (2002). Features of the structure of mucuscontaining cells in the pericarp of achenes of some species of the genus Artemisia (Asteraceae). Botanicheskii Zhurnal, 87(9), 1-9. (In Russian)

\section{Карпологічні особливості деяких представників роду Artemisia, поширених в Україні}

Тетяна Вакуленко *, Тетяна Багацька, Ольга Корабльова **, Іван Гурненко, Джамал Рахметов

Національний ботанічний сад імені М.М. Гришка НАН України, вул. Тимірязєвська, 1, Київ, 01014, Україна; * botanicukr@gmail.com, ** okorablova@ukr.net

Досліджено мікроморфологічну будову сім'янок шести видів роду Artemisia (A. absinthium, A. annua, A. argyi, A. dracunculus, A. marschalliana та A. vulgaris), представлених у флорі України, з метою виявити карпологічні ознаки, які можуть слугувати діагностичними для визначенні цих видів.

Плоди збирали з дикорослих рослин рекреаційних зон міста Києва, та тих, що зростають на колекційній ділянці Національного ботанічного саду імені М.М. Гришка НАН України. Макроморфологічні особливості вивчали за допомогою бінокулярного мікроскопа Stemi 2000, Carl Zeiss. Ультраструктуру поверхні вивчали за допомогою растрового електронного мікроскопа JSM-6700F, JEOL у режимі вторинної електронної емісії. Напилення вуглецем здійснювали методом вакуумного термічного випаровування вакуумного універсального поста ВУП-5M, SELMI; напилення платиною - за допомогою пристрою іонно-плазмового травлення JFC-1600, JEOL.

Усі досліджені види мають добре виражений, справжній, багатоклітинний, симетричний, багаторядний карпоподій, який, однак, відрізняється за формою. Тип поверхні у А. аппиа визначено як сітчасто-ямковий, що зумовлено структурою екзокарпа та екзотестами, розташованими під ним. Виявлено види з лопатевим або суцільним верхівковим обідком, а також такі, у яких обідок навколо місця прикріплення віночка відсутній. Встановлено, що первинна ультраструктура плодів спричинена формою та характером розташування слизових клітин; епідермальні клітини екзокарпа переважно стиснуті, без чітких меж. В той час як вторинна ультраструктура плодів зумовлена переважно тонкою і непомітною кутикулою, іноді зморшкуватою, з прошарками і невеликими наростами. Досліджені карпологічні ознаки можуть бути додатковими критеріями та використовуватись у комплексі з іншими ознаками для точнішої ідентифікації досліджених видів.

Ключові слова: Asteraceae, Artemisia, карпоподіум, слизові комплекси, первинна ультраструктура, вторинна ультраструктура, плід 